\title{
Examining Proactive Strategic Decision-Making Flexibility in New Product Development
}

\author{
Destan Kandemir and Nuran Acur
}

While strategic flexibility is widely accepted as a prerequisite for a firm's success, its application in strategic decision making to a firm's new product development (NPD) activities is limited to only a few studies. Furthermore, many organizations still have difficulties creating proactive strategic flexibility in their decision-making processes. Past research studies have largely ignored the relationship between strategic decision-making flexibility and firms' resources and/or capabilities and success in the context of NPD. This study advances strategic flexibility by adopting the proactive approach of NPD decision-making flexibility and by examining its role in translating organizational resources and capabilities into NPD success. This study draws upon the resources, capabilities (i.e., flexibility), and performance framework to show how proactive strategic decision-making flexibility plays a crucial role in developing new products that can create new opportunities and comply with market needs. Therefore, this research aims to (1) develop an operational definition of strategic decision-making flexibility and (2) propose a framework to understand the drivers and the subsequent new product performance outcomes of strategic decision-making flexibility. This study adopts the proactive perspective of strategic decision-making flexibility and defines it as a capability that enables firms to develop NPD strategies to respond to future changes in the environment.

The analysis, based on data collected from 103 European firms, shows that that the effects of long-term orientation, strategic planning, internal commitment, and innovative climate on proactive strategic decision-making flexibility are significant. The findings indicate specifically the roles of both champions and gatekeepers, who infuse a firm's knowledge with a clear understanding of its resources, constraints, and market needs, thereby enhancing decision makers' motivation to behave proactively to precipitate transformation. The results also reveal a positive association between proactive strategic decision-making flexibility and NPD performance outcomes. As such, strategic flexibility provides firms with an ability to adapt to changing environments and to create new market opportunities, product, and technological arenas, and to deliver successful new products. When firms open new market, technological, and product arenas, they can easily foresee their new demands and changes and successfully deliver new products, meeting customer needs/demands, and offering benefits such as quality, cost, and timeliness. This study therefore provides a valuable reference point for future research in strategic decision-making flexibility in NPD.

\section{Introduction}

$\mathrm{T}$ oday's turbulent business environment has generated new opportunities and challenges for firms. In such environments, firms must have the capability to change their strategic options. As suggested by the resource-based view (e.g., Barney, 1991; Peteraf, 1993; Wernerfelt, 1984), a firm's dynamic capabilities allow it to create new products and processes and to foresee changing market conditions; these are the core of its competitiveness. Thus, strategic flexibility is an important capability that enables firms to modify and foresee

Address correspondence to: Destan Kandemir, Department of Management, Bilkent University, Bilkent, Ankara 06800, Turkey. E-mail: destan@ bilkent.edu.tr. Tel: +90-312-290-1526. innovation strategies in response to current or future changes in the environment (Evans, 1991; Johnson, Lee, Saini, and Grohmann, 2003; Sanchez, 1995). These dynamic capabilities shape a firm's managerial and organizational processes, its position, and its paths (Nelson and Winter, 1982; Teece, Pisano, and Shuen, 1997).

In product competition, strategic flexibility in decision making becomes especially necessary for firms to increase the speed as well as the range of their strategic maneuvers (Evans, 1991; Sanchez, 1995; Volberda, 1996). Here, strategic maneuvers represent "preferential access to future opportunities" (Bowman and Hurry, 1993, p. 762) and are dependent on the resources available to firms as well as their capabilities in applying those resources to alternative courses of action. Specific strategic flexibilities manifested in strategic maneuvers may be 
unique to firms and may enable them to achieve exceptional levels of performance in dynamic markets (Barney, 1991; Wernerfelt, 1984).

There is, accordingly, a large and growing literature on strategic decision making as well as on strategic flexibility, at the level of the product (Eisenhardt, 1990; Sanchez, 1995) and organization as a whole (Elbanna, 2006; Evans, 1991; Hitt, Keats, and de Marie, 1998; Rajagopalan, Rasheed, and Datta, 1993; Sharfman and Dean, 1997). Some scholars have suggested that in product competition, strategic decision-making flexibility enables firms to maintain multiple simultaneous alternative characteristics of effective new product development (NPD) decision making (Eisenhardt, 1990; Sanchez, 1995). Other authors have supported this argument by stating that strategic decision making is an organization's essential ability to adapt its survival and renewal processes (Ansoff, 1975; Evans, 1991) for NPD success (Debruyne et al., 2002; Sanchez, 1995; Verganti, 1999). While strategic flexibilities are widely accepted as prerequisites for a firm's success, their application in strategic decision making relating to a firm's NPD activities is limited to only a few studies (Aaker and Mascarenhas, 1984; Atuahene-Gima and Li, 2004). As suggested by Sharfman and Dean (1997), good opportunities exist for studying strategic flexibility because strategic choices are the most important adaptations and reactions that firms make. Indeed, many organizations still have difficulties with creating strategic flexibility in their NPD decisionmaking processes (Atuahene-Gima and Li, 2004;

\section{BIOGRAPHICAL SKETCHES}

Dr. Destan Kandemir is an assistant professor of marketing at Bilkent University, Ankara, Turkey. She received her Ph.D. in marketing from Michigan State University. Her research focuses on new product development, market orientation, strategic alliances, and customer relationship management. Her publications have appeared in Journal of Management, Journal of the Academy of Marketing Science Journal of International Marketing, and Industrial Marketing Management.
}

Dr. Nuran Acur is a senior lecturer at the University of Strathclyde, UK, and associate professor of operations and innovation strategy at Ozyegin University in Turkey. She received her Ph.D. in strategic management from the University of Strathclyde. Previously, she worked at Aalborg University and Bilkent University. She has been serving as a board member of European Operations Management Association since 2006. She has published articles in the areas of operations strategy, product innovation, and service innovation. Her work has appeared in JPIM, International Journal of Operations and Production Management, Creativity and Innovation Management, Supply Chain Management: An International Journal, and other scholarly journals.
Sanchez, 1995). To this end, the resource-based view of the firm (Barney, 1991; Wernerfelt, 1984) and a strategic decision-making framework are integrated to identify the necessary organizational drivers that give rise to strategic flexibility in NPD decision making. Therefore, this research aims to (1) develop an operational definition of strategic-decision-making flexibility and (2) propose a framework to understand the drivers and the subsequent new product performance outcomes of strategic decisionmaking flexibility.

This study adopts the proactive perspective of strategic decision-making flexibility and defines it as a capability that enables firms to develop NPD strategies to respond to future changes in the environment (Evans, 1991; Johnson et al., 2003; Sanchez, 1995). Strategic decision-making flexibility occurs from resources and coordination mechanisms inside organizations (Sanchez, 1995). Building upon recommendations of resourcebased theorists, a firm's resources and organizational capabilities are considered primary determinants of proactive strategic decision-making flexibility in NPD (Kleinschmidt, de Brentani, and Salomo, 2007). Therefore, this study makes advances in applying resourcebased theory to proactive strategic decision-making flexibility in NPD and explores its role in three ways: First, this study is one of the earliest attempts at conceptualizing and operationalizing the proactive dimension of strategic decision-making flexibility in NPD. Next, it explores which resources are necessary for creating a proactive strategic flexibility associated with NPD decision making. Finally, the study shows how proactive strategic decision-making flexibility can contribute to NPD success (i.e., strategic performance in terms of creating product market opportunities, and their fit with market demands, which refers to a firm's ability to achieve certain product attributes). By separating the effects of proactive strategic decision-making flexibility, a better understanding of its role in enhancing NPD success occurs. Moreover, practical applications of this study's theoretical model and its empirical examination should provide managers with lessons in flexible decision making to achieve a competitive advantage in dynamic product markets.

\section{Theoretical Background}

\section{Proactive Strategic Decision-Making Flexibility in NPD}

This study views strategic decision-making flexibility as a dynamic capability that enables firms to make effective 
strategic decisions by maintaining multiple simultaneous decision alternatives (Atuahene-Gima and Li, 2004; Eisenhardt and Zbaracki, 1992; Sanchez, 1995). In this way, it plays an important role in adapting to changes in markets, technology, and competition (Aaker and Mascarenhas, 1984; Evans, 1991; Nadkarni and Narayanan, 2007). These capabilities are closely entwined with the NPD decision process, which encompasses idea generation to market launch.

Many important and valuable innovations are complex and often originate within the adaptive organization. Firms with greater flexibilities are able to quickly alter their product development decisions to react to their environments' changing markets and technological opportunities and/or to seize the initiative and steer these changes to their advantage (Gerwin, 1993; Grewal and Tansuhaj, 2001; Johnson et al., 2003; Sanchez, 1995). Thus, strategic flexibility can be either reactive (Buckley and Casson, 1998; Matusik and Hill, 1998) or proactive in nature (Evans, 1991; Gerwin, 1993; Hitt et al., 1998; Johnson et al., 2003). From a reactive perspective, firms might need strategic flexibilities to respond to diverse scenarios, including market threats or opportunities (Johnson et al., 2003; Volberda, 1996). In the face of economic crises or rapid changes in industries, it may be useful for firms to take reactive action and to build up a capability to cope with changes arising from demand, technology, or competition (Evans, 1991; Grewal and Tansuhaj, 2001). Flexibility is often considered as an adaptive capability to respond to environmental uncertainty (Gerwin, 1993). However, firms may try to influence markets and to create competitive advantages through "creative destruction" by introducing product innovations that make current products and associated organizational knowledge and skills obsolete (Schumpeter, 1934). Such entrepreneurial firms are characterized by their forward-looking perspectives and their willingness to change the nature of competition (Dess and Lumpkin, 2005). In dynamic product competition, proactive strategic flexibility becomes critical for creating uncertainties for a firm's rivals and thus putting them in the position of having to respond to successful product market initiatives (Dess and Lumpkin, 2005; Gerwin, 1993). The capabilities associated with strategic decision making can be viewed as part of a "surprise management" approach, which necessitates early detection and analysis of strategic options (Ansoff, 1975). Hence, this study views proactive strategic decisionmaking flexibility as a firm's ability to seek and foresee new opportunities as well as to adopt strategic decisions for an unknown environmental contingency (Ansoff, 1975).

\section{Resource-Based View of a Firm}

NPD can be seen as an ongoing strategic decisionmaking process that requires the commitment of many resources and capabilities that are designed to control market direction and opportunity creation. As suggested by the resource-based view of a firm (Barney, 1991; Wernerfelt, 1984), innovation confers a competitive advantage on the firm through its capability of generating unique, inimitable, valuable, and diversified products and hence enhancing its survival prospects and performance. In a similar vein, Sanchez (1995) proposes that strategic flexibility depends jointly on a firm's resource flexibilities and capabilities and on how it applies them to multiple courses of action in NPD. Worren, Moore, and Cardona (2002) also suggest that "it is important to consider complex sets of organizational resources in understanding how strategic flexibility results in competitive advantage" (p. 1125). As an important dynamic capability in NPD, proactive strategic decision-making flexibility involves the deployment of resources. This flexibility engages processes embedded in firms and evolves over time. Hence, it reflects the firm's deliberate investments in continuously learning and capturing the lessons from its prior experiences as well as those of others. Moreover, as proactive strategic decision-making flexibility is hard to imitate and acquire in product markets, it creates rents for firms. Accordingly, this study proposes a conceptual model that integrates the resources needed for creating proactive strategic decision-making flexibility and its NPD performance outcomes.

The process perspective of strategic decision making (Elbanna, 2006) is adopted to identify the necessary resources engaged with the NPD process to develop proactive strategic flexibility (Calantone, Garcia, and Dröge, 2003). The three multifaceted dimensions of the strategic decision-making process are rationality, political behavior, and intuition (Elbanna, 2006; Elbanna and Child, 2007; Rajagopalan et al., 1993).

Rationality refers to the extent to which decision makers follow an explicit (formal), systematic, and analytical approach (Atuahene-Gima and Li, 2004; Dean and Sharfman, 1996; Fredrickson, 1984) toward long-term organizational goals (Langley, 1989). Accordingly, rationality is closely related to strategic planning because it involves systematic screening of new product ideas and market opportunities, careful assessment of NPD resource requirements, and defining and articulating the aims and objectives of new product strategy in relation to overall organization strategy (Calantone et al., 2003; Cooper, Edgett, and Kleinschmidt, 2002; Cormican and 
O’Sullivan, 2004; Kahn, Barczak, and Moss, 2006; Song and Montoya-Weiss, 1998). Rationality can also be linked to long-term orientation, which represents organizational values emphasizing the future (Geletkanycz, 1997), for example, collecting and using information to identify possibilities for growth and development (Dess and Lumpkin, 2005; Miller, Kets de Vries, and Toulouse, 1982).

Political behavior is characterized by the interaction of interests, conflict, and power (Elbanna, 2006). It considers not only the politics among organizational members but also their attempts to influence decision outcomes (Dean and Sharfman, 1996). Those dedicated to the NPD project should not only resolve conflicts of interest between an organization's members but also manage information flows within and between organizations and advance and expedite projects toward completion (Markham and Griffin, 1998; Page, 1993; Song and Parry, 1997). Hence, it is important to understand how successful new product decision-making flexibility emerges from those committed individuals who stimulate awareness of opportunities and ensure that projects are given a high resource priority, even those encountering difficulties (Markham and Griffin, 1998; Reid and de Brentani, 2004; Song and Parry, 1997). Thus, political behavior is associated with internal commitment.

Intuition is the third dimension of the strategic decision-making process. It is concerned with a reliance on judgment and experience, and the use of "gut feeling" (Eisenhardt, 1989; Elbanna and Child, 2007). Miller and Ireland (2005) define intuition in strategic decision making as "expertise" and "holistic hunch," which could be valuable when an organization has adopted exploration or opportunity recognition as a goal. Moreover, they suggest that "beyond telling an inspirational story to help sell a strategic decision made on the basis of hunch, upper-echelon executives could develop an organizational climate supportive of risk taking and failure" (p. 24). Hunches often involve risk taking, experimenting with novel ideas, and departing from usual practices. These actions are consistent with the characteristics of an innovative climate. This kind of climate guides a firm's behaviors and decision-making processes in NPD and also drives proactive decisions that initiate change (Deshpandé and Farley, 2004; Fredrickson, 1985; Johannessen, Olsen, and Olaisen, 1999). Thus, intuition is related to innovative climate.

Based on the resource-based view of a firm, two types of rents that accrue to a firm as a result of its resources and capabilities are considered: (1) strategic performance, which is the extent to which NPD programs can open new market, product, and technological arenas
(Cooper and Kleinschmidt, 2000; Kleinschmidt et al., 2007) and (2) fit with market demands, which refers to the ability of firms to develop new products that meet customers' needs/demands and offer benefits such as quality, timeliness, and cost (Brown and Eisenhardt, 1995; Im and Workman, 2004).

\section{Hypotheses}

\section{Long-Term Orientation}

Firms holding a longer term view of their NPD efforts assume an importance of strategic decision making that involves a series of sequential, rational, and analytical processes (Cooper, Edgett, and Kleinschmidt, 2004a, 2004b; Hitt and Tyler, 1991). Moreover, in such firms, strategic decision making is guided by a set of long-term objectives. Long-term-oriented firms recognize that environments are dynamic and view adjustments as essential to creating a superior customer value in dynamic product markets where there is a high level of uncertainty about the future strategic value of resources (Hofstede, 1993). Because such firms systematically scan environments for alternative future product strategies and carefully analyze this information in the final product decision, they can actively preempt or generate activity in the environment (Evans, 1991; Johnson et al., 2003). That is, long-term orientation enables firms to proactively manipulate their competitors and customers by creating a range of strategic product market options before they are needed (Evans, 1991; Miller and Toulouse, 1986). Thus,

$$
\begin{aligned}
& \text { H1: A firm's long-term orientation is positively related to } \\
& \text { its proactive strategic decision-making flexibility. }
\end{aligned}
$$

\section{Strategic Planning}

Research studies suggest that a rationally planned product development effort is essential for success (Calantone et al., 2003; Cooper, Edgett, and Kleinschmidt, 2004c; Cooper and Kleinschmidt, 2007; Cormican and O'Sullivan, 2004; Kahn et al., 2006; Salomo, Weise, and Gemunden, 2007). Firms use strategic planning to create and select a portfolio of development projects to achieve leading products, to integrate and coordinate the functional units that are involved in the development process, and to align the development projects to their overall strategy (Cooper et al., 2004b; Cormican and O'Sullivan, 2004; Karlsson and Ahlstrom, 1997). Strategic planning allows firms to focus their searches for new product ideas, assists them in the selection of development projects at 
gate meetings and portfolio reviews, and helps them prioritize projects so that they can direct their efforts to the most critical products and markets (Brown and Eisenhardt, 1995; Cooper et al., 2004b; Krishnan and Ulrich, 2001; Liberatore and Stylianou, 1995).

Drawing upon the rationality perspective of strategy (Andrews, 1971; Hofer and Schendel, 1978), a firm's proactive strategic decision-making capabilities embedded in its NPD decision processes are expected to be influenced by a systematic search for product alternatives, careful analysis of these alternative scenarios, and a rational selection procedure (Brown and Eisenhardt, 1995; Salomo et al., 2007). Moreover, firms with strategic planning simultaneously proceed with several development projects at different phases and thus can achieve a balance in the number of projects (incremental versus radical and/or short term versus long term) and available resources (Cooper et al., 2002; Kahn et al., 2006). This, in turn, enables them to create a capacity to be agile and versatile by means of developing a variety of response repertoires. Thus,

H2: A firm's strategic planning is positively related to its proactive strategic decision-making flexibility.

\section{Internal Commitment}

Internal commitment is defined as the existence of a group of individuals that supports and forwards NPD projects toward completion and successful commercialization (Song and Parry, 1997). It entails interaction of interests, conflict, and power, and thus involves political and social processes within the firm that may influence NPD decisions (Elbanna, 2006). Because power and interest play an important role in influencing opportunity recognition and future strategic choices such as resource allocations (Goodstein, Boeker, and Stephan, 1996; Pfeffer and Salancik, 1978), internal commitment to a project is expected to influence a firm's proactive strategic decision-making flexibility in NPD. Specifically, the commitment of gatekeepers and champions throughout the NPD process are considered in this study.

Gatekeepers are individuals who funnel information from the external environment into an organization and decide whether or not to share information with others (Brown and Eisenhardt, 1995; Ettlie and Elsenbach, 2007; MacDonald and Williams, 1994; Reid and de Brentani, 2004; Tushman and Katz, 1980). According to the Product Development and Management Association Handbook of Product Development, a champion is described as "a person who takes an inordinate interest in seeing that a particular process or product is fully devel- oped or marketed. The role varies from situations calling for little more than stimulating awareness of the opportunity to extreme cases where the champion tries to force a project past the strongly entrenched internal resistance of company policy or that of objecting parties" (Rosenau, Griffin, Castellion, and Anscheutz, 1996, p. 519). To be successful, champions should have excellent diplomatic skills and know-how to approach and win over different types of people on a one-to-one basis (Gupta and Wilemon, 1990; Hauschildt and Kirchmann, 2001). Because innovation can be viewed as information processes that involve searching for, processing, and transferring information, managing those information flows plays an important role in successful innovations (Rogers, 1982). Along these lines, it is reasonable to argue that the roles of champions and gatekeepers are closely linked and that their presence is critical in NPD projects; gatekeepers filter and direct external information, and champions push new ideas and gather resources to keep projects alive (MacDonald and Williams, 1994; Reid and de Brentani, 2004; Roberts and Fusfeld, 1981).

Drawing upon the roles of gatekeepers and champions, internal commitment involves political tactics that may be brought into NPD decision making. These tactics may involve the use of power (Krishnan and Park, 2003), manipulation and control of crucial information (Pettigrew, 1973), as well as timing (Hickson, Butler, Cray, Mallory, and Wilson, 1986) and influence the decision processes in several ways (Elbanna, 2006). Firms can enhance their capabilities to respond to market threats and opportunities in a proactive manner by leveraging gatekeepers and champions in the NPD process. The primary contribution of gatekeepers is to recognize market or new technology opportunities and subsequently to generate the needed internal support from people throughout the organization (Appleyard, Brown, and Sattler, 2006; MacDonald and Williams, 1994; Markham and Aiman-Smith, 2001; Tushman and Katz, 1980). Project champions are also shown to positively affect intermediate NPD outcomes such as reduced cycle times, increased NPD strategy innovativeness, enhanced project performance, and assist with overcoming obstacles in NPD processes (Gupta and Wilemon, 1990; Markham and Aiman-Smith, 2001; Markham and Griffin, 1998; Tushman and Katz, 1980). They facilitate the external communication of decision makers and enable them to anticipate changes in dynamic product markets (Katz and Tushman, 1981; Liberatore and Stylianou, 1995). The commitment of both gatekeepers and champions throughout the NPD process should enable firms to increase the development speed and to extend the scope 
of their strategic new product options even before they are needed. Thus,

H3: A firm's internal commitment is positively related to its proactive strategic decision-making flexibility.

\section{Innovative Climate}

A firm's innovative climate represents its receptivity to new ideas and innovations (Hurley and Hult, 1998; Zaltman, Duncan, and Holbek, 1973). Siguaw, Simpson, and Enz (2006) identify three important components of innovative climates. First, innovative climates are supportive of learning that reinforces creativity (Scott and Bruce, 1994), openness to new ideas (Zaltman et al., 1973), and positive attitudes toward risk (Atuahene-Gima and Ko, 2001). Second, innovative climates stimulate organization-wide commitment to faster and more innovations (Amabile, 1997; Hurley and Hult, 1998; Worren et al., 2002). Third, they create a unifying enthusiasm and devotion among employees, and thus drive organizations to act as collective bodies rather than separate functional units aspiring to succeed through innovation (Amabile, 1997; Worren et al., 2002). Because firms with an innovative climate encourage experimentation, risk taking, and organization-wide commitment to innovation, they embrace intuition as an effective approach to decision making. Intuitive processes primarily rely on judgment (Bunge, 1975; Daft and Lengel, 1986), learning from experience (Nutt, 1998; Wally and Baum, 1994), and the use of gut feeling (Parikh, 1994), which together can influence NPD decision making. Although the role of innovative climates in strategic flexibility is recognized (Worren et al., 2002), the research has been mostly anecdotal (Hitt et al., 1998; Volberda, 1996). Because innovative climates can influence the way firms filter and interpret environmental stimuli (Daft and Weick, 1984), and thus the configuration and speed of their new product decisions (Calantone et al., 2003; Siguaw et al., 2006; Volberda, 1996), this study explores the relationship between an innovative climate and a proactive strategic decision-making flexibility in NPD.

In innovative climates, intuition can expedite decision making by making it easier for people to agree on what product objectives and decisions are vital and what alternatives are worth pursuing based on judgment and experience rather than computational routines (Burke and Miller, 1999; Daft and Lengel, 1986; Miller and Ireland, 2005). Because firms with innovative climates encourage novel approaches and actions that run counter to prevailing thinking and do not penalize failures (Barczak, Sultan, and Hultink, 2007; Worren et al., 2002), they allow for product choices made by trusting one's gut feeling. When decision makers cannot access complete, accurate, and timely information, intuition can be a form of intelligence in decision making to evaluate and seize project alternatives (Nutt, 1998; Parikh, 1994). Moreover, innovative climates eliminate communication barriers among various functions and encourage them to work together (Brown and Eisenhardt, 1995; Cooper et al., 2004a). This unification stimulates the emergence of collective intuition among decision makers, which, in turn, enables them to quickly identify and detect evolving environmental opportunities and threats (Eisenhardt, 1999). Hence,

\section{H4: A firm's innovative climate is positively related to its proactive strategic decision-making flexibility.}

\section{NPD Performance Outcomes}

Empirical research has demonstrated the positive impact of strategic flexibility on business performance (Bierly and Chakrabarti, 1996; Grewal and Tansuhaj, 2001; Swamidas and Newell, 1987; Worren et al., 2002). Drawing upon the resource-based view of a firm, those with greater proactive strategic decision-making flexibility are expected to achieve better NPD performance outcomes, namely strategic performance and fit with market demands (Barney, 1991; Evans, 1991).

Proactive strategic decision-making flexibility provides firms with a variety of preemptive responses and enables them to act on unforeseen changes in the environment (Evans, 1991; Grewal and Tansuhaj, 2001). Those firms can anticipate changes in market demands or emerging problems and position themselves to take advantage of any beneficial future outcomes (Dess and Lumpkin, 2005; Evans, 1991). By increasing the scope and implementation speed of their strategic alternatives, such firms can achieve degrees of freedom to do things differently and to inflict surprise on competitors or to change the nature of competition (Eppink, 1978; Evans, 1991; Sanchez, 1995). Moreover, they should be able to quickly alter their product development decisions to recognize new product initiatives and steer them to their advantage (Gerwin, 1993; Johnson et al., 2003; Sanchez, 1995). As a result of these greater capabilities, firms are expected to achieve better strategic performance by introducing new products or technological capabilities and by entering new markets ahead of the competition. Thus,

H5a: A firm's proactive strategic decision-making flexibility is positively related to the strategic performance of its NPD program. 
Moreover, firms with proactive strategic flexibility in their NPD processes are expected to enhance their products' fit with market demands. That is, they should be able to deliver new products that fulfill customer needs/ demands, to bring new products into market in a timely manner, to achieve good quality, and to gain satisfactory development costs (Griffin and Hauser, 1993; Li and Calantone, 1998). Such firms not only recognize changes in their environment but also act on those insights before their competitors do. As such, they can preempt the competition with more current versions of the product (Calantone et al., 2003). Because proactive strategic decision-making flexibility increases a firm's range of preemptive actions, it can launch more new products, introduce broader product lines, and/or upgrade existing products more rapidly (Sanchez, 1995). Thus,

H5b: A firm's proactive strategic decision-making flexibility is positively related to the fit of its NPD program with market demands.

Finally, this study investigates the relationship between the strategic performance of a firm's NPD program and its fit with market demands. Research suggests that new products that are first to market contain the most recent ideas and technological advances, are associated with higher product quality, and are perceived as more current (Atuahene-Gima, 2003; Carbonell and Rodriguez, 2006; Kessler and Bierly, 2002). Consistent with these findings, firms with higher capabilities of identifying and taking advantage of valuable pioneering opportunities are shown to possess new products that are more responsive to market needs (Cooper and Kleinschmidt, 2000; Kleinschmidt et al., 2007). NPD projects and activities that enable firms to break into new market, product, and technological arenas are expected to be better able to meet customers' needs/demands, deliver new products on time, and offer better cost and quality benefits. Thus,

H6: The strategic performance of a firm's NPD program is positively related to its fit with market demands.

\section{Methodology}

The data used in this study were drawn from a study designed to gather information about the NPD practices and performance of companies in a variety of European industries and countries. This project thus builds on a common database containing descriptions of a large number and variety of NPD configurations from each participating country in terms of "operational effectiveness" and "strategic flexibility" performance. Dillman's
(2000) method for mail and Internet-based surveys was used to develop the questionnaire. Ten NPD managers and six academics reviewed the draft questionnaire to identify and resolve any unfamiliar or unclear wording.

Research has shown that some European countries have similar NPD practices to each other (e.g., Souder and Jenssen, 1999; van Riel, Lemmink, and Ouwersloot, 2004). For the above-mentioned project, data were collected from NPD/research and development (R\&D) managers of 103 companies in Denmark (30), Finland (13), Norway (8), and the Netherlands (52) in the food, automotive, electronics, and biotechnology industries with at least five or more full-time equivalent employees in NPD. The data were pooled and used to test the hypotheses proposed in this study. The surveys (all in English) were administered by research coordinators in each of the countries.

The primary unit of analysis in this study was the NPD program of independent firms and strategic business units of larger firms. An e-mail list was obtained from different databases: the European Patent Office database, the Federation for the Metal and Electro-technical Industries database in the Netherlands, the Nnerhverv ( Industry Names and Numbers) database in Denmark, and the Voitto database in Finland. The managers were contacted by telephone, invited to participate in the survey, and offered a report with the findings from the study as an incentive to participate. Only those willing to participate were sent the questionnaire. Following the initial invitation, two reminder e-mails were sent at two-week intervals, and follow-up telephone calls were conducted. The response rate for the total sample was approximately $12 \%$. Annual sales of the participating firms ranged from one million to 4.5 billion Euros. Firm size, measured by the number of full-time employees, varied from six to 30,000.

To assess nonresponse bias, a test for comparing the averages of annual sales and the number of employees of early and late respondents was conducted (Armstrong and Overton, 1977). Because the data collection started at the same time in all four countries, the responses were pooled initially and then sorted based on the date they were received. The $t$-tests between mean responses of early and late respondents indicated no statistically significant differences at the .05 level. Overall, there was no problem with nonresponse bias in the data.

\section{Measures}

A list of potentially useful measures was developed based on the NPD and strategic management literature. When existing scales were unavailable, new scales and measures were developed using the framework proposed by 
Churchill (1979). Constructs were defined, an item pool was generated, and the format of measurement was decided on. The initial item pool was reviewed by a number of experts in academia and industry. On the basis of this review, some statements were dropped, and a few were modified. Table 1 details the constructs and their operationalization.

Long-term orientation was developed using two items based on Cooper et al.'s (2004b) discussion about the role of a long-term focus in achieving NPD success. These two items evaluate the extent to which a firm's NPD strategy is guided by long-term performance goals. Strategic planning was measured using five items adopted from Cooper and Kleinschmidt's (1995) and Cooper et al.'s (2004c) best-practice scales. The 5-item scale tapped the identification of formal NPD strategies and the use of project portfolio management. Internal commitment was measured using two items assessing the commitment of a "project champion" and a "gatekeeper," roles identified as critical to NPD success (Roberts and Fusfeld, 1981; Song and Parry, 1997). Although individuals' commitment contributed to the total internal commitment, the items measuring each type of commitment did not need to be correlated. Therefore, the operational definition of internal commitment was done through a formative measure. Innovative climate was measured using three items adopted from Glick's (1985) description of organizational climate and Ekvall's (1996) definition and operationalization of organizational climate.

Proactive strategic decision-making flexibility was developed for this study using six items. This construct assessed a firm's ability to anticipate future requirements (i.e., time, speed, and commitment) of NPD processes as well as to adopt product development decisions for an unknown environmental contingency (Griffin, 1997).

Strategic performance was measured using six items adapted from Griffin and Page (1996), Cooper and Kleinschmidt (2000), and Kleinschmidt et al. (2007). This construct evaluated the extent to which a firm's NPD projects open new markets, product, and technological arenas. Finally, fit with market demands was measured using four items adapted from Chiesa, Coughlan, and Voss (1996). Together, these four items assessed the extent to which a firm can achieve new products consisting of the following attributes: unique benefits, timeliness, cost, and quality (Brown and Eisenhardt, 1995; Draaijer, 1993).

\section{The Measurement Model}

A confirmatory factor analysis (CFA) using the maximum likelihood estimation procedure with the raw data as input in EQS 6.1 (Bentler, 1995) was performed to assess the measurement model (Gerbing and Anderson, 1988). Because involvement was operationalized as a formative scale, it was not included in the CFA analysis. After items with low factor loadings or high cross loadings were dropped, the confirmatory model fit the data satisfactorily. Table 1 presents the key results of the CFA.

Next, the convergent and discriminant validity of the constructs were assessed. Each measurement item loaded only on its latent construct. The chi-square test for the theoretical variables was not statistically significant $\left(\chi_{[137]}^{2}=145.36, p>.05\right)$. The Bentler-Bonett nonnormed fit index (NNFI), the comparative fit index (CFI), Bollen's incremental fit index (IFI), and the root mean square error of approximation (RMSEA) indicated a good fit with the hypothesized measurement model $(\mathrm{NNFI}=.98, \mathrm{CFI}=.99, \mathrm{IFI}=.99$, and RMSEA $=.025)$ (Hu and Bentler, 1999) (Table 1). Furthermore, all the factor loadings were statistically significant $(p<.01)$, and the composite reliabilities of all constructs were equal to, or exceeded, the threshold value of .70 (Nunnally, 1978). Thus, the measures demonstrate adequate convergent validity and reliability.

Discriminant validity was examined by calculating the shared variance between all possible pairs of constructs, verifying that they were lower than the average variance extracted for the individual constructs (Fornell and Larcker, 1981). As presented in Table 1, these results showed that the average variance extracted by the measure of each factor was larger than the squared correlation of that factor's measure with all measures of the other factors in the model. Given these values, all the factors in the measurement model possess strong discriminant validity. In light of this evaluation, it can be concluded that all factors in the measurement model possess both convergent and discriminant validity and that the CFA model fits the data adequately.

\section{Results}

The proposed model was tested using structural equation modeling with the EQS 6.1 program. The results are summarized in Table 2, along with the parameter estimates, their corresponding $t$-values, and the fit statistics. Although the chi-square test is statistically significant $\left(\chi^{2}{ }_{[158]}=196.18, p<.05\right)$, the Bentler-Bonett NNFI, CFI, Bollen's IFI, and RMSEA indicate that the theoretical model has a good fit to the data $(\mathrm{NNFI}=.93$, $\mathrm{CFI}=.94, \quad \mathrm{IFI}=.95$, and $\mathrm{RMSEA}=.049) \quad(\mathrm{Hu}$ and Bentler, 1999). 
Table 1. Results of the Confirmatory Factor Analysis

Scale Items

Standardized

Loading

$t$-value ${ }^{\mathrm{a}}$

Long-term orientation (7-point semantic scale)

$\mathrm{AVE}=69.2 \% ; \mathrm{HSV}=26 \% ; \mathrm{CR}=.80$

We primarily focus on long-term growth.

We mainly focus on long-term performance of our NPD function.
We primarily focus on short-term profit. ${ }^{\text {rc }}$

We mainly focus on short-term performance of our NPD function. ${ }^{\text {ro }}$
.96

.68

6.46

Strategic planning (7-point Likert scale ranging from "strongly agree" to "strongly disagree")

$\mathrm{AVE}=58.9 \% ; \mathrm{HSV}=22 \% ; \mathrm{CR}=.80$

The role of NPD in achieving business goals is clearly articulated.

There is a formally stated NPD strategy.

We have clearly defined goals for all our individual new products. ${ }^{c}$

Systematic project portfolio management is in place.

The project portfolios are aligned with the business strategy.

Internal commitment ${ }^{\mathrm{b}}$ (6-point scale ranging from "limited to one phase" to "throughout the whole NPD process")

Gatekeeper

Collects and channels information about important changes in the internal and external environments.

Passes information on to others.

Champion

Sells new ideas to others in the organization and gets resources.

Recognizes, proposes, and pushes a new technical idea for formal management approval.

Innovative climate (7-point Likert scale ranging from "strongly agree" to "strongly disagree")

$\mathrm{AVE}=45.5 \% ; \mathrm{HSV}=18 \% ; \mathrm{CR}=.70$

There is a strong support for further development of new ideas.

People are involved in debates about differing viewpoints.

High risk-taking behavior is tolerated.

Strategic decision-making flexibility (7-point scale ranging from "not at all achieved" to "very well achieved")

$\mathrm{AVE}=50 \% ; \mathrm{HSV}=22 \% ; \mathrm{CR}=.80$

We can estimate future requirements on our total development time.

We are able to adjust our NPD process to future time requirements. ${ }^{c}$

We can estimate future requirements on the speed of our NPD decision-making process. ${ }^{c}$

We are able to adjust our NPD decision-making process to future requirements.

We are able to forecast the future requirements on the commitment to translating our NPD decisions into actions.

We are able to adjust the commitment to translating NPD decisions into actions to the requirements.

Strategic performance (7-point scale ranging from "not at all achieved" to "very well achieved")

$\mathrm{AVE}=49.8 \% ; \mathrm{HSV}=26 \% ; \mathrm{CR}=.80$

Our current development projects include new product market options. ${ }^{c}$

We prefer NPD projects that generate options for future product development.

NPD is successful in opening new markets to our organization.

NPD is successful in leading our organization into new product areas.

Our NPD activities open new technologies to our organization. ${ }^{\text {c }}$

We incorporate solution unarticulated customer needs in our new products.

Fit with market demands (7-point scale ranging from "not at all achieved" to "very well achieved")

$\mathrm{AVE}=54.8 \% ; \mathrm{HSV}=15 \% ; \mathrm{CR}=.80$

Our new products meet customer requirements.

Our new products are delivered on time.

The cost of our new products is satisfactory.

The quality of our products is good.

Model fit statistics: $\chi^{2}=145.44(\mathrm{df}=137, p>.05)$

$\mathrm{NNFI}=.98$

$\mathrm{CFI}=.99$

$\mathrm{IFI}=.99$

RMSEA $=.025$

$90 \%$ confidence interval of RMSEA $=(.00, .05)$

${ }^{a}$ The $t$-values from the unstandardized solution.

${ }^{\mathrm{b}}$ Average variance extracted, highest shared variance, and reliability are not applicable for formative scales.

${ }^{\mathrm{c}}$ Removed items.

AVE, average variance extracted; HSV, highest shared variance with other constructs; CR, composite reliability; rc, reverse coded; df, degrees of freedom;

NNFI, nonnormed fit index; CFI, comparative fit index; IFI, incremental fit index; RMSEA, root mean square error of approximation. 
Table 2. Results of Hypothesis Testing

\begin{tabular}{|c|c|c|c|c|c|}
\hline \multirow[b]{2}{*}{ Independent Variables } & \multicolumn{5}{|c|}{ Dependent Variables } \\
\hline & $\begin{array}{l}\text { Proactive Strategic } \\
\text { Decision-Making } \\
\text { Flexibility }\end{array}$ & $\begin{array}{c}\text { Strategic } \\
\text { Performance }\end{array}$ & $\begin{array}{l}\text { Fit with Market } \\
\text { Demands }\end{array}$ & Hypotheses & Conclusion \\
\hline Long-term orientation & $.32 * * *(2.46)$ & & & $\mathrm{H} 1$ & Supported \\
\hline Strategic planning & $.48 * * * *(3.89)$ & & & $\mathrm{H} 2$ & Supported \\
\hline Internal commitment & $.12 *(1.40)$ & & & $\mathrm{H} 3$ & Supported \\
\hline Innovative climate & $.38 * * * *(3.11)$ & & & $\mathrm{H} 4$ & Supported \\
\hline Proactive strategic & & $.38 * * * *(3.48)$ & & $\mathrm{H} 5 \mathrm{a}$ & Supported \\
\hline Decision-making flexibility & & & $.27 * *(2.12)$ & $\mathrm{H} 5 \mathrm{~b}$ & Supported \\
\hline Strategic performance & & & $.25 * *(2.11)$ & H6 & Supported \\
\hline $\begin{array}{l}\text { Model fit statistics: } \chi^{2}=196 \\
\text { NNFI }=.93 \\
\text { CFI }=.94 \\
\text { IFI }=.95 \\
\text { RMSEA }=.049 \\
90 \% \text { confidence interval o }\end{array}$ & $\begin{array}{l}=158, p<.05) \\
\mathrm{EA}=(.02, .07)\end{array}$ & & & & \\
\hline
\end{tabular}

Note: $t$-values are in parentheses.

$* * * * p<.001, * * * p<.01, * * p<.05, * p<.1$ (one-tailed $t$-test).

df, degrees of freedom; NNFI, nonnormed fit index; CFI, comparative fit index; IFI, incremental fit index; RMSEA, root mean square error of approximation.

The results, which appear in Table 2, indicate that a firm's long-term orientation $(\beta=.32 ; p<.01)$, strategic planning $(\beta=.48 ; \quad p<.001)$, internal commitment $(\beta=.12 ; \quad p<.1)$, and innovative climate $(\beta=.38$; $p<.001)$ have positive effects on its proactive strategic decision-making flexibility. Thus, H1, H2, H3, and H4 are supported. $\mathrm{H} 5$ predicts that high levels of proactive strategic decision-making flexibility will improve NPD performance outcomes. The results show that proactive strategic decision-making flexibility positively impacts both strategic performance $(\beta=.38 ; p<.001)$ and fit with market demands $(\beta=.27 ; p<.05)$, which confirm $\mathrm{H} 5 \mathrm{a}$ and H5b, respectively. Finally, the strategic performance of a firm's NPD program $(\beta=.25 ; p<.05)$ is found to increase its fit with market demands, in support of H6.

\section{Discussion of Results}

This study adopts resources, capabilities, and the performance paradigm to show which resources are necessary to develop a proactive strategic decision-making flexibility and how that flexibility plays a crucial role in creating new opportunities and complying with customers' expectations. The results show that the direct effects of long-term orientation, strategic planning, internal commitment, and an innovative climate on proactive strategic decision-making flexibility are significant. Moreover, strategic performance and fit with market demands are positively influenced by proactive strategic decision- making flexibility. Finally, strategic performance is found to be positively related to fit with market demands.

$\mathrm{H} 1$ predicts that there is a positive link from long-term orientation to proactive strategic decision-making flexibility. The results support H1, which is consistent with Homburg and Jensen's (2007) suggestion that long-term orientation affects decision making. When firms emphasize short-term orientation, they might only respect traditional practices and get locked into institutionalized thinking about opportunities and changes in environments, which might result in rigidities in a firm's NPD decision-making processes. Conversely, emphasizing long-term orientation enables firms to effectively foresee emerging demands and changes in the environment (Cooper et al., 2004b; Quinn, 1985) and to carefully analyze judgments on resource investments. In sum, long-term orientation is likely to be significantly important for strategic adaptation as well as for anticipating changing environments (Geletkanycz, 1997) and thus is essential for proactive strategic decision-making flexibility. As would be expected, strategic planning positively impacts proactive strategic decision-making flexibility, which supports H2. Based on this result, it can be concluded that strategic planning enhances strategic flexibility by means of defining clear NPD activities, looking for future market opportunities, and identifying latent customer needs (Cooper et al., 2002).

The results also support $\mathrm{H} 3$, which shows that internal commitment to a product development project is important for developing proactive strategic decision-making 
flexibility. Several researchers support the finding that a firm's capacity to acquire and process information, which is linked to internal commitment, affects the success of a decision-making process (Eisenhardt, 1999) and also drives flexibility in strategic options (Sharfman and Dean, 1997). The findings point specifically to the roles of both champions and gatekeepers, who infuse a firm's knowledge with a clear understanding of its resources, constraints, and market needs (Markham and Griffin, 1998; O'Connor and Rice, 2001), thereby enhancing decision makers' motivation to behave proactively to precipitate transformation. Champions and gatekeepers together help generate a variety of decision-making options and drive toward completion NPD product and process opportunities toward completion (Griffin, 1997; Song and Parry, 1997).

The positive impact of innovative climates on proactive strategic decision-making flexibility seems almost inevitable (H4). Miles and Snow (1978) explain that innovative climates enable firms to exploit and find new product and market opportunities, which can be translated into competitive advantages. This is consistent with Sanchez's (1995) findings, suggesting that flexibility in NPD competition is associated with better coordination between people and resources in rapidly changing environments.

The results also show that the interplay between proactive strategic decision-making flexibility and NPD performance is significant, in support of $\mathrm{H} 5 \mathrm{a}$ and $\mathrm{H} 5 \mathrm{~b}$. As expected, strategic flexibility provides firms with an ability to adapt to changing environments and to create new market opportunities, product, and technological arenas, and to deliver successful new products.

Finally, H6 predicts that there is a positive relationship between strategic performance and fit with market demands. The results support H6, which is consistent with Cooper and Kleinschmidt (2000) and Kleinschmidt et al. (2007), who suggested that strategic performance of a firm's NPD program affects the fit with market demands. When firms open new market, technological, and product arenas, they can easily foresee their new demands and changes and successfully deliver new products, meeting customer needs/demands and offering benefits such as quality, cost, and timeliness.

\section{Conclusions and Future Work}

This study contributes to the empirical application of strategic flexibility for NPD decision-making processes. The relatively few research studies in strategic management to date focus on the proactive dimension of strategic decision-making flexibility (Nutt, 1993; Sharfman and Dean, 1997). To the best of the authors' knowledge, this paper is also the first empirical study to develop and advance the notion of strategic decision-making flexibility for NPD.

Drawing upon both the resource-based view and the strategic decision-making process, this study identified long-term orientation and strategic planning (rationality), internal commitment (political behavior), and innovative climate (intuition) as factors that influence proactive strategic decision-making flexibility. Past research studies largely ignore the relationship between strategic decision-making flexibility and firms' resources and success in the context of NPD. The results suggest that organizational resources have the potential to influence proactive strategic decision-making flexibility and are consistent with the findings of Fredrickson (1985) and Eisenhardt (1989), who suggest that managers can be simultaneously rational and intuitive. Both studies show that although managers or decision makers may collect information from different sources, they focus on only a few of them to adapt to environmental changes. It appears that these managers use a combination of rationality and intuition in their decision making processes. Although these findings are more suggestive than conclusive, their replication would make it possible to identify separate characteristics of strategic decision making (rationality, political behavior, and intuition) for creating proactive strategic flexibility. This study therefore provides a valuable reference point for future research in strategic decision-making flexibility in NPD.

Researchers have argued that the complexity of strategic decision processes influences NPD success (Atuahene-Gima and Li, 2004; Fredrickson, 1984). As such, changes in environments become problematic if critical decision options are not clear or, more importantly, when it is difficult to precipitate and adapt to external changes (Atuahene-Gima and Li, 2004; Bierly and Chakrabarti, 1996). In this regard, the results suggest that strategic planning, internally committed members (i.e., gatekeepers and champions), and innovative climates become important to manage the flow of information inside organizations (MacDonald and Williams, 1994). Consequently, the approach adopted here is broadly in line with recent arguments in the resourcebased view that intangible resources (e.g., climate, longterm values, commitment, and NPD strategy) are more likely to comply with changes in the dynamic environment (Cooper et al., 2004a, 2004b, 2004c; Cooper and Kleinschmidt, 1995). Therefore, this research provides a valuable starting point for future research to examine 
alternative resources that may affect proactive strategic decision-making flexibility in NPD. Theories concerned with how strategic flexibility is determined should be formulated to take these results into account.

Although these research results initiate a new research direction using less-defined constructs (i.e., internal commitment and long-term orientation) to examine how firms' resources affect the flexibility of the strategic decision-making process, this study has not investigated how these resources operate. For example, how champions and gatekeepers actually influence other people during the decision-making process has not been investigated.

Another limitation of this research is related to the unit of analysis: the NPD level. There may be some decisionlevel factors, such as decision uncertainty and decision importance, that interact with NPD-level and firm-level determinants of flexibility in a decision-making process. Accordingly, further research could consider exploring the interaction effects of such variables on strategic decision-making flexibility in NPD.

There is also a methodological improvement that others might employ when extending this study. Common method bias is an important methodological concern where data on the key dependent variable (i.e., NPD performance outcomes in this study) are derived from the same source as the data on the key independent variables (i.e., proactive strategic decision-making flexibility in this study), and it is an acknowledged limitation of this study. Future researchers can alleviate this problem by obtaining objective data on the dependent variable.

Furthermore, this study only considers the proactive dimension of strategic flexibility and provides preliminary evidence for the development of a proactive flexibility in NPD decision processes. In turbulent environments, it becomes even more important to make proactive and reactive decisions in a timely manner. Small windows of opportunity, economic crises, and overly aggressive competitors may intensify turbulent conditions. In such environments, firms should also seriously consider reactive decision making. For example, the current global credit crunch, which had its epicenter in the United States and Western Europe, has shown that any market economy may face financial instability, corporate failures, loss of consumer and business confidence, and subsequent economic recession in a world of global finance. However, this research has concentrated on the normal course of a firm's business and ignored how firms respond to challenges posed by economic crises, which might create opportunities to reframe problems and realize innovative solutions. When Finland and Sweden faced vast eco- nomic crises in the early 1990s, expenditure on R\&D, education, and innovative capabilities dramatically increased, not only for their governments but also for firms in general. Many firms in these countries transformed the crises into opportunities, and as a result, Swedish and Finnish businesses emerged as global leaders in product innovation in sectors such as telecom and machinery. The recent global economic recession poses a valuable opportunity to examine reactive strategic flexibility in product innovation.

This study was not designed to collect the information necessary to identify reactive strategic flexibility and to judge the relative importance of this alternative form of strategic flexibility. Therefore, future studies would benefit from incorporating different forms of flexibility in decisions that allow for reactive adaptations to changing environments and proactive approaches to driving change. Future research might usefully address such questions as: (1) How can firms' strategic flexibility capabilities be used to facilitate a decision-making model that contributes to the emergence and sustainability of innovative organizations during external environment changes such as world economic recession? (2) Is there room for firms that focus exclusively either on their adaptability (reactive) or on their ability to foresee future opportunities (proactive) in product innovations? And (3) How do firms' reactive or proactive strategic flexibility capabilities support NPD projects? In view of the growing importance of strategic flexibility in NPD for maintaining the competitiveness of business in nearly every industry, answers to such questions should be a top priority for NPD managers and academics alike.

\section{Implications for Managerial Practice}

Three insights derived from this research on proactive strategic decision-making flexibility may be of particular interest to senior and NPD managers and should be incorporated into their managerial practices. First, managers might need to acknowledge the importance of flexibility in the strategic decision-making process and to consider the relationship between the three dimensions of this process and the level of flexibility. Examples such as Silicon Valley-based firm IDEO (Kelley and Littman, 2001) have shown that initiatives coming from all levels of an organization can be the source of new creative products and future success. Thus, firms should seek NPD initiatives and ideas within their organizations and sometimes use intuition in decision making. In addition, firms should provide a supportive climate for innovation, and organizations' members should be active players in 
the strategic decision-making process. To create the appropriate culture, managers can openly and consistently support individuals, understanding the concept that winners may take risks and sometimes fail. Next, the process through which strategic decision-making flexibility is achieved holds potential for competitive advantage and requires purposeful strategic planning. Hence, managers can leverage decision-making processes through strategic planning.

Finally, for NPD managers and senior managers, the results emphasize the importance of maintaining an open relationship among an organization's members, and being aware of the possible politics involved, for example, regarding gatekeepers, product managers, and decision makers. As gatekeepers decide what information to share and communicate with others, they may at times restrict the information flow. Hence, managers may make decisions based on incomplete information, and this could lead to stagnation.

\section{References}

Aaker, D. A., and B. Mascarenhas. 1984. The need for strategic flexibility. Journal of Business Strategy 5: 74-82.

Amabile, T. M. 1997. Motivating creativity in organizations: On doing what you love and loving what you do. California Management Review 40 (1): 39-58.

Andrews, K. 1971. The concept of corporate strategy. Homewood, IL: Richard D. Irwin.

Ansoff, H. I. 1975. Managing strategic surprise by response to weak signals. California Management Review 18 (2): 21-33.

Appleyard, M. M., C. Brown, and L. Sattler. 2006. An international investigation of problem-solving performance in the semiconductor industry. Journal of Product Innovation Management 23: 147-67.

Armstrong, J. S., and T. S. Overton. 1977. Estimating nonresponse bias in mail surveys. JMR, Journal of Marketing Research 14 (3): 396-402.

Atuahene-Gima, K. 2003. The effects of centrifugal and centripetal forces on product development speed and quality: How does problem solving matter? Academy of Management Journal 46 (3): 359-73.

Atuahene-Gima, K., and A. Ko. 2001. An empirical investigation of the effect of market orientation and entrepreneurship orientation alignment on product innovation. Organization Science 12 (1): 54-74.

Atuahene-Gima, K., and H. Li. 2004. Strategic decision comprehensiveness and new product development outcomes in new technology ventures. Academy of Management Journal 47 (4): 583-97.

Barczak, G., F. Sultan, and E. J. Hultink. 2007. Determinants of IT usage and new product performance. Journal of Product Innovation Management 24 (6): 600-13.

Barney, J. 1991. Firm resources and sustained competitive advantage. Journal of Management 17 (1): 99-120.

Bentler, P. M. 1995. EQS structural equations program manual. Encino, CA: Multivariate Software.

Bierly, P. E. III, and A. K. Chakrabarti. 1996. Technological learning, strategic flexibility, and new product development in the pharmaceutical industry. IEEE Transactions on Engineering Management 43 (4): 368-82.

Bowman, E. H., and D. Hurry. 1993. Strategy through the option lens: An integrated view of resource investments and the incremental choice process. Academy of Management Review 18: 760-82.
Brown, S. L., and K. M. Eisenhardt. 1995. Product development: Past research, present findings, and future. Academy of Management Review 20 (2): 343-78.

Buckley, P. J., and M. C. Casson. 1998. Models of the multinational enterprise. Journal of International Business Studies 29: 21-44.

Bunge, M. 1975. Intuition and science. Westport, CT: Greenwood Press.

Burke, L. A., and M. K. Miller. 1999. Taking the mystery out of intuitive decision making. Academy of Management Executive 13: 91-99.

Calantone, R., R. Garcia, and C. Dröge. 2003. The effects of environmental turbulence on new product development strategy planning. Journal of Product Innovation Management 20 (2): 90-103.

Carbonell, P., and A. I. Rodriguez. 2006. The impact of market characteristics and innovation speed on perceptions of positional advantage and new product performance. International Journal of Research in Marketing 23: 1-12.

Chiesa, V., P. Coughlan, and C. A. Voss. 1996. Development of a technical innovation audit. Journal of Product Innovation Management 13 (2): $105-36$.

Churchill, G. A. Jr. 1979. A paradigm for developing better measures of marketing constructs. JMR, Journal of Marketing Research 16 (February): 64-73.

Cooper, R. G., S. J. Edgett, and E. J. Kleinschmidt. 2002. Optimizing the stage-gate process: What best-practice companies do-II. Research Technology Management 45 (6): 43-49.

Cooper, R. G., S. J. Edgett, and E. J. Kleinschmidt. 2004a. Benchmarking NPD practices-I. Research Technology Management 47 (1): 31-43.

Cooper, R. G., S. J. Edgett, and E. J. Kleinschmidt. 2004b. Benchmarking NPD practices-II. Research Technology Management 47 (3): 50-59.

Cooper, R. G., S. J. Edgett, and E. J. Kleinschmidt. 2004c. Benchmarking NPD practices-III. Research Technology Management 47 (3): 43-55.

Cooper, R. G., and E. J. Kleinschmidt. 1995. Performance typologies of new product projects. Industrial Marketing Management 24: 439-56.

Cooper, R. G., and E. J. Kleinschmidt. 2000. New product performance: What distinguishes the star products. Australian Journal of Management 25 (1): 17-46.

Cooper, R. G., and E. J. Kleinschmidt. 2007. Winning the businesses in product development: The critical success factors. Research Technology Management 50 (3): 52-66.

Cormican, K., and D. O'Sullivan. 2004. Auditing best practice for effective product innovation management. Technovation 24: 819-29.

Daft, R. L., and R. H. Lengel. 1986. Organizational information requirements, media richness and structural design. Management Science 32: 554-71.

Daft, R. L., and K. E. Weick. 1984. Toward a model of organizations as interpretation systems. Academy of Management Review 9 (2): 284-95.

Dean, J. W., and M. P. Sharfman. 1996. Does decision process matter? A study of strategic decision making effectiveness. Academy of Management Journal 39: 368-96.

Debruyne, M., M. Rudy, A. Griffin, S. Hart, E. J. Hultink, and H. Robben. 2002. The impact of new product launch Strategies on competitive reaction in industrial markets. Journal of Product Innovation Management 19 (2): 159-70.

Deshpandé, R., and J. U. Farley. 2004. Organizational culture, market orientation, innovativeness, and firm performance: An international research odyssey. International Journal of Research in Marketing 21: $3-22$.

Dess, G. G., and G. T. Lumpkin. 2005. The role of entrepreneurial orientation in stimulating effective corporate entrepreneurship. Academy of Management Executive 19 (1): 147-56.

Dillman, D. A. 2000. Mail and internet surveys: The tailored design method. New York: John Wiley \& Sons.

Draaijer, D. J. 1993. Market-oriented manufacturing systems: Theory and practice. Enschede: University of Twente. 
Eisenhardt, K. M. 1989. Making fast strategic decisions in high velocity environments. Academy of Management Journal 32 (3): 543-76.

Eisenhardt, K. M. 1990. Speed and strategic choice: How managers accelerate decision-making. California Management Review 32 (3): 39-54.

Eisenhardt, K. M. 1999. Strategy as strategic decision making. MIT Sloan Management Review 40 (3): 65-72.

Eisenhardt, K. M., and M. J. Zbaracki. 1992. Strategic decision making. Strategic Management Journal 13 (8): 17-37.

Ekvall, G. 1996. Organizational climate for creativity and innovation. European Journal of Work and Organizational Psychology 5 (1): 105-23.

Elbanna, S. 2006. Strategic decision-making: Process perspectives. International Journal of Management Reviews 8 (1): 1-20.

Elbanna, S., and J. Child. 2007. Influence on strategic decision effectiveness: Development and test of an integrative model. Strategic Management Journal 28: 431-53.

Eppink, D. J. 1978. Planning for strategic flexibility. Long Range Planning 11 (August): 9-15.

Ettlie, J. E., and J. M. Elsenbach. 2007. The changing role of R\&D gatekeepers. Research Technology Management 50: 59-66.

Evans, J. S. 1991. Strategic flexibility for high technology manoeuvres: A conceptual framework. Journal of Management Studies 28 (1): 69-89.

Fornell, C., and D. F. Larcker. 1981. Evaluating structural equation models with unobservable variables and measurement error. JMR, Journal of Marketing Research 18: 39-50.

Fredrickson, J. W. 1984. The comprehensiveness of strategic decision processes: Extension, observations, future directions. Academy of Management Journal 27 (3): 445-65.

Fredrickson, J. W. 1985. Effects of decision motive and organizational performance level on strategic decision processes. Academy of Management Journal 28 (4): 821-43.

Geletkanycz, M. A. 1997. The salience of "culture's consequences": The effects of cultural values on top executive commitment to the status quo. Strategic Management Journal 18 (8): 615-34.

Gerbing, D. W., and J. C. Anderson. 1988. An updated paradigm for scale development incorporating unidimensionality and its assessment. JMR, Journal of Marketing Research 25 (2): 186-92.

Gerwin, D. 1993. Manufacturing flexibility: A strategic perspective. Management Science 39 (4): 395-410.

Glick, W. H. 1985. Conceptualizing and measuring organizational and psychological climate: Pitfalls in multilevel research. Academy of Management Review 10 (3): 601-16.

Goodstein, J., W. Boeker, and J. Stephan. 1996. Professional interests and strategic flexibility: A political perspective on organizational contracting. Strategic Management Journal 17 (7): 577-86.

Grewal, R., and P. Tansuhaj. 2001. Building organizational capabilities for managing economic crisis: The role of market orientation and strategic flexibility. Journal of Marketing 65 (2): 67-80.

Griffin, A. 1997. PDMA research on new product development practices: Updating trends and benchmarking best practices. Journal of Product Innovation Management 14 (6): 429-58.

Griffin, A., and J. R. Hauser. 1993. The voice of the customer. Marketing Science 12 (1): 1-27.

Griffin, A., and A. L. Page. 1996. PDMA success measurement project: Recommended measures for product development success and failure. Journal of Product Innovation Management 13: 478-96.

Gupta, A. K., and D. L. Wilemon. 1990. Accelerating the development of technology-based new products. California Management Review 32 (2): $24-44$

Hauschildt, J., and E. Kirchmann. 2001. Teamwork for innovation-The "troika" of promotors. $R \& D$ Management 31 (1): 41-49.

Hickson, D. J., R. J. Butler, D. Cray, G. R. Mallory, and D. C. Wilson. 1986. Top decisions: Strategic decision-making in organizations. Oxford: Basil Blackwell.
Hitt, M. A., B. W. Keats, and S. M. de Marie. 1998. Navigating in the new competitive landscape: Building strategic flexibility and competitive advantage in the 21st century. Academy of Management Executive 12 (4): $22-42$

Hitt, M. A., and B. B. Tyler. 1991. Strategic decision models: Integrating different perspectives. Strategic Management Journal 12 (5): 327-51.

Hofer, C. W., and D. Schendel. 1978. Strategy formulation: Analytical concepts. St. Paul, MN: West Publishing.

Hofstede, G. 1993. Cultural constraints in management theories. Academy of Management Executive 7: 81-94.

Homburg, C., and O. Jensen. 2007. The thought worlds of marketing and sales: Which differences make a difference? Journal of Marketing 71 (3): $124-42$.

Hu, L., and P. M. Bentler. 1999. Cutoff criteria for fit indexes in covariance structure analysis: Conventional criteria versus new alternatives. Structural Equation Modeling 6: 1-55.

Hurley, R. F., and G. T. M. Hult. 1998. Innovation, market orientation, and organizational learning: An integration and empirical examination. Journal of Marketing 62: 42-54.

Im, S., and J. P. Workman. 2004. Market orientation, creativity, and new product performance in high-technology firms. Journal of Marketing 68 (2): 114-32.

Johannessen, J.-A., B. Olsen, and J. Olaisen. 1999. Aspects of innovation theory based on knowledge-management. International Journal of Information Management 19 (2): 121-39.

Johnson, J. L., R. P. Lee, A. Saini, and B. Grohmann. 2003. Market-focused strategic flexibility: Conceptual advances and an integrative model. Journal of the Academy of Marketing Science 31 (1): 74-89.

Kahn, K. B., G. Barczak, and R. Moss. 2006. Perspective: Establishing an NPD best practices framework. Journal of Product Innovation Management 23 (2): 106-16.

Karlsson, C., and P. Ahlstrom. 1997. Perspective: Changing product development strategy - A managerial challenge. Journal of Product Innovation Management 14 (6): 473-84.

Katz, R., and M. Tushman. 1981. An investigation into the managerial roles and career paths of gatekeepers and project supervisors in a major $\mathrm{R} \& \mathrm{D}$ facility. $R \& D$ Management 11: 103-10.

Kelley, T., and J. Littman. 2001. The art of innovation. London: Profile Books.

Kessler, E. H., and P. H. Bierly. 2002. Is faster really better? An empirical test of the implications of innovation speed. IEEE Transactions on Engineering Management 49: 2-12.

Kleinschmidt, E. J., U. de Brentani, and S. Salomo. 2007. Performance of global new product development programs: A resource-based view. Journal of Product Innovation Management 24 (5): 419-41.

Krishnan, H. A., and D. Park. 2003. Power in acquired top management teams and post-acquisition performance: A conceptual framework International Journal of Management 20 (1): 75-80.

Krishnan, V., and K. T. Ulrich. 2001. Product development decisions: A review of the literature. Management Science 47 (1): 1-21.

Langley, A. 1989. In search of rationality: The purpose behind the use of formal analysis in organizations. Administrative Science Quarterly 34: 598-631.

Li, T., and R. J. Calantone. 1998. The impact of market knowledge competence on new product advantage: Conceptualization and empirical examination. Journal of Marketing 62: 13-29.

Liberatore, M. J., and A. C. Stylianou. 1995. Expert support systems for new product development decision making: A modeling framework and applications. Management Science 41 (8): 1296-316.

MacDonald, S., and C. Williams. 1994. The survival of the gatekeeper. Research Policy 23 (2): 123-32.

Markham, S. K., and L. Aiman-Smith. 2001. Product champions: Truths, myths and management. Research Technology Management 44 (3): $44-50$. 
Markham, S. K., and A. Griffin. 1998. The breakfast of champions: Associations between champions and product development environments, practices and performance. Journal of Product Innovation Management 15 (5): 436-54.

Matusik, S. F., and C. W. Hill. 1998. The utilization of contingent work, knowledge creation, and competitive advantage. Academy of Management Review 23 (October): 680-97.

Miles, R. E., and C. C. Snow. 1978. Organizational strategy, structure, and process. New York: McGraw-Hill.

Miller, C. C., and R. D. Ireland. 2005. Intuition in strategic decision making: Friend or foe in the fast-paced 21st century. Academy of Management Executive 19: 19-30.

Miller, D., M. F. R. Kets de Vries, and J.-M. Toulouse. 1982. Top executive locus of control and its relationship to strategy-making, structure, and environment. Academy of Management Journal 25 (2): 237-53.

Miller, D., and J.-M. Toulouse. 1986. Chief executive personality and corporate strategy and structure in small firms. Management Science 32 (11): $1389-409$.

Nadkarni, S., and V. K. Narayanan. 2007. Strategic schemas, strategic flexibility, and firm performance: The moderating role of industry clockspeed. Strategic Management Journal 28 (3): 243-70.

Nelson, R., and S. Winter. 1982. An evolutionary theory of economic change. Cambridge, MA: Harvard University Press.

Nunnally, J. 1978. Psychometric theory. New York: McGraw-Hill.

Nutt, P. C. 1993. Flexible decision styles and the choices of top executives. Journal of Management Studies 30 (5): 695-721.

Nutt, P. C. 1998. Framing strategic decisions. Organization Science 9 (2): 195-216.

O'Connor, G. C., and M. P. Rice. 2001. Opportunity recognition and breakthrough innovation in large established firms. California Management Review 43 (2): 95-116.

Page, A. L. 1993. Assessing new product development practices and performance: Establishing crucial norms. Journal of Product Innovation Management 10 (4): 273-90.

Parikh, J. I. 1994. Intuition: The frontier of management. Oxford: Blackwell Business.

Peteraf, M. A. 1993. The cornerstones of competitive advantage: A resource-based view. Strategic Management Journal 14 (3): 179-91.

Pettigrew, A. 1973. The politics of organizational decision-making. London: Tavistock.

Pfeffer, J., and G. R. Salancik. 1978. The external control of organizations: A resource dependence perspective. New York: Vintage.

Quinn, J. B. 1985. Managing innovation: Controlled chaos. Harvard Business Review 63 (3): 73-85.

Rajagopalan, N., A. M. Rasheed, and D. K. Datta. 1993. Strategic decision processes: Critical review and future directions. Journal of Management 19 (2): 349-84.

Reid, S. E., and U. de Brentani. 2004. The fuzzy front end of new product development for discontinuous innovations: A theoretical model. Journal of Product Innovation Management 21 (3): 170-84.

Roberts, E. B., and A. R. Fusfeld. 1981. Staffing the innovative technology based organisation. Sloan Management Review Spring: 19-34.

Rogers, E. M. 1982. Information exchange and technological Innovation. In The transfer and utilization of technical knowledge, ed. D. Shal, 10523. Lexington, MA: Lexington Books.
Rosenau, M. D., A. Griffin, G. A. Castellion, and N. F. Anscheutz. 1996. PDMA handbook on new product development. New York: John Wiley $\&$ Sons.

Salomo, S., J. Weise, and H. G. Gemunden. 2007. NPD planning activities and innovation performance: The mediating role of process management and the moderating effect of product innovativeness. Journal of Product Innovation Management 24 (4): 285-302.

Sanchez, R. 1995. Strategic flexibility in product competition. Strategic Management Journal 16: 135-59.

Schumpeter, J. A. 1934. The theory of economic development. Cambridge: Harvard University Press.

Scott, S. G., and R. A. Bruce. 1994. Determinants of innovative behavior: A path model of individual innovation in the workplace. The Academy of Management Journal 37 (3): 580-607.

Sharfman, M. P., and J. W. Dean. 1997. Flexibility in strategic decision making: Informational and ideological perspectives. Journal of Management Studies 34 (2): 191-217.

Siguaw, J. A., P. M. Simpson, and C. A. Enz. 2006. Conceptualizing innovation orientation: A framework for study and integration of innovation research. Journal of Product Innovation Management 23 (6): $556-74$.

Song, X. M., and M. M. Montoya-Weiss. 1998. Critical development activities for really new versus incremental products. Journal of Product Innovation Management 15 (2): 124-35.

Song, X. M., and M. E. Parry. 1997. A cross-national comparative study of new product development processes: Japan and the United States. Journal of Marketing 61 (2): 1-18.

Souder, W. E., and S. A. Jenssen. 1999. Management practices influencing new product success and failure in the United States and Scandinavia: A cross-cultural comparative study. Journal of Product Innovation Management 16 (2): 183-203.

Swamidas, P. M., and W. T. Newell. 1987. Manufacturing strategy, environmental uncertainty and performance: A path analytic model. Management Science 33 (4): 509-24.

Teece, D. J., G. Pisano, and A. Shuen. 1997. Dynamic capabilities and strategic management. Strategic Management Journal 18 (7): 509-33.

Tushman, M. L., and R. Katz. 1980. External communication and project performance: An investigation into the role of gatekeepers. Management Science 26 (11): 1071-85.

van Riel, A. C. R., J. Lemmink, and H. Ouwersloot. 2004. High-technology service innovation success: A decision-making perspective. Journal of Product Innovation Management 21 (5): 348-59.

Verganti, R. 1999. Planned flexibility: Linking anticipation and reaction in product development projects. Journal of Product Innovation Management 16 (4): 363-76.

Volberda, H. W. 1996. Toward the flexible form: How to remain vital in hypercompetitive environments. Organization Science 7 (4): 359-75.

Wally, S., and J. R. Baum. 1994. Personal and structural determinants of the pace of strategic decision-making. Academy of Management Journal 37: 932-56.

Wernerfelt, B. 1984. A resource-based view of the firm. Strategic Management Journal 5: 171-80.

Worren, N., K. Moore, and P. Cardona. 2002. Modularity, strategic flexibility, and firm performance: A study of the home appliance industry. Strategic Management Journal 23: 1123-40.

Zaltman, G., R. Duncan, and J. Holbek. 1973. Innovations and organizations. New York: John Wiley \& Sons. 